\title{
Trade Unions, the Gig Economy, and the Feminisation of Work: Lessons from the Past?
}

\author{
REBECCA ZAHN*
}

\section{Introduction}

The world of work is changing rapidly, and concerns abound that 'non-standard' forms of work are challenging the social and collective dimension of work. In particular, the rapid growth of the 'gig economy' has brought these concerns to the forefront of the debate. For trade unions, the growth in non-standard work has long been considered problematic. However, the high degree of individualisation and lack of human contact characterising the gig economy raise profound questions about how trade unions should both organise, and represent, workers in this 'sector' at a time when trade union membership is in decline and there is a continuing lack of legislative support for collective bargaining. Much of the debate in the existing literature takes as its point of departure, the 'standard' (male) worker, and sees the rise in 'non-standard' work and work in the gig economy as a threat to this model. This is despite the fact that trade unions have been challenged by 'non-standard' work since their inception: the non-standard arrangements, which have now entered the mainstream, have long been the norm for many women workers. ${ }^{1}$ Yet historically, within the labour law and industrial relations literature, women and gender have rarely been the subject of discussion, although this has changed since the 1980 s. $^{2}$ In addition, much of the British literature examining the novelty of the gig economy

\footnotetext{
* Senior Lecturer in Law, University of Strathclyde. I am grateful to the editors of this collection, Erika Kovàcs, Lydia Hayes, Jeremias Prassl, a number of anonymous reviewers, and the participants and discussants at the workshop, Theorising Labour in a Changing World: New Perspectives and Approaches, held at the University of Maastricht in December 2016 for providing invaluable comments on earlier drafts. The usual disclaimers apply.

${ }^{1}$ See K Rittich, 'Feminization and Contingency: Regulating the Stakes of Work for Women' in J Conaghan, RM Fischl and K Klare (eds), Labour Law in an Era of Globalization: Transformative Practices and Possibilities (Oxford, Oxford University Press, 2004) 117.

${ }^{2}$ Feminist scholarship mainly emerged in the 1980 s and there is now a rich and diverse body of literature. For an excellent overview, see the footnotes in J Conaghan, 'Labour Law and Feminist Method' (2017) 33 International Journal of Comparative Labour Law and Industrial Relations 93; J Fudge, 'From Women and Labour Law to
} 
has focussed on the scope and ability of labour law to respond to these work arrangements, and there has been less engagement with trade union responses to these 'new' forms of work, even though the growth in such work also creates pressure for changes in the institutions that regulate labour markets.

Against this background, and in light of this book's overarching theme, this chapter calls for a new research agenda that considers the challenges of non-standard work, and of work in the gig economy, for trade unions within the context of the 'feminisation of work'. The geographical focus of this chapter, in this regard, is the UK. The chapter argues that trade unions are struggling to shake off their image as the representatives of white, working-class, and blue-collar men. As a result, many of the successful efforts at organising non-standard workers, including workers in the gig economy, have been undertaken by 'non-traditional' trade unions (and other forms of grassroots organisations). This raises the question as to whether 'traditional' trade unions are able to effectively respond to the rise of non-standard forms of work, and to the gig economy in particular. It is suggested that part of the difficulty for these trade unions lies in the way in which they prioritise the functions that they adopt within the labour market, and the labour law system; functions which are based on a gendered understanding of the labour market, ${ }^{3}$ and which in turn hamper trade union efforts to reach out to an increasingly feminised labour force. The chapter therefore suggests that a conscious conceptual shift should take place, when thinking about the purpose of trade unions, if these organisations are to respond effectively to the feminisation of work.

\section{The Rise of Non-Standard Work and the Gig Economy in a Changing Legal Landscape}

There is a considerable and diverse body of literature which examines the changing nature and composition of labour - which uses various terms such as precarious, non-standard, contingent, atypical, insecure, and flexible to describe it. ${ }^{4}$ Global economic factors and the changing contours of work, and workplace relations, have led to a reorientation of the social, economic, political, and cultural environment within which labour law has developed, as well as precipitating a changing role for labour law itself. ${ }^{5}$ While collective bargaining in conjunction with legal intervention to protect workers who fell outside its sphere used to be the primary

Putting Gender and Law to Work' in M Davies and VE Munro (eds), The Ashgate Research Companion to Feminist Legal Theory (Farnham, Ashgate, 2013) 321. There are still relatively few works that examine trade unions and women. For an overview of the debates, see S Fredman, Women and the Law (Oxford, Clarendon Press, 1997). Other works are cited as appropriate throughout this chapter.

${ }^{3}$ J Fudge and R Owens, 'Precarious Work, Women, and the New Economy: The Challenge to Legal Norms' in J Fudge and R Owens (eds), Precarious Work, Women and the New Economy: The Challenge to Legal Norms (Oxford, Hart Publishing, 2006) 3.

4 For comprehensive references to the debate, see ibid, 10; N Kountouris, 'The Legal Determinants of Precariousness in Personal Work Relations: A European Perspective' (2012) 34 Comparative Labor Law \& Policy Journal 21.

${ }^{5}$ See further Fudge and Owens, 'Precarious Work' (n 3$) 5$. 
source of protection for workers in the UK, in the post-war era ${ }^{6}$, individual rights were increasingly extended during the 1960s and 1970s to workers both within and outside the collective bargaining arena. Instead of targeting workers considered particularly vulnerable, the legislation introducing individual rights was based on two general principles: first, that the floor of rights should not be available to those who were entrepreneurs in their own right; and second, that some rights at least must be 'earned' by a period of service with the employer.

From 1979, labour law was increasingly used as a tool to 'reduce the burdens on business', and thereby to facilitate a low-cost flexible workforce. Labour law policies were driven by the view that a low cost and highly flexible workforce was essential for increased competitiveness and lower unemployment. ${ }^{7}$ This entailed the adoption of a series of measures, including the removal of minimum wage protection, the weakening of trade unions, and diminishing the coverage of employment protection legislation, as well as facilitating a ready-supply of low cost labour both within and from outside the UK. ${ }^{8}$ Marginal workers were seen as attracting not more, but less, protection from the law than standard workers; a policy decision which had a 'disproportionately serious impact on women' ${ }^{9}$ who were over-represented in non-standard work. Although the (then) European Community took a different approach, any attempts at establishing a floor of social rights and European-wide collective bargaining structures have also faltered in recent years. ${ }^{10}$ At the same time, the reform of welfare and tax regimes encouraged a fundamental shift away from the male breadwinner employment norm to a new multi-earner family model, whereby women were actively encouraged to work outside the household. ${ }^{11}$ This had a profound impact on women's labour, and labour market participation, at a time when there has been an 'intensification and erosion of gender in the labour market' ${ }^{12}$ Following the 1997 election, a 'Third Way' developed under the New Labour government which rejected both the earlier neoliberal view, and the post-war consensus, that employment standards are a 'burden on business' and, instead, considered employment rights as facilitating productive and committed non-standard workers. ${ }^{13}$

In addition to these policy decisions, which reshaped the legal framework regulating the work relationship and had a knock-on effect on the constitution of the labour market, factors

\footnotetext{
${ }^{6}$ Subsequent paragraphs summarise Fredman's argument in: S Fredman, 'Labour Law in Flux: The Changing Composition of the Workforce' (1997) 26 Industrial Law Journal 337. See also Lord Wedderburn, 'Labour Law 2008: 40 Years On' (2007) 36 Industrial Law Journal 397.

${ }^{7}$ See S Deakin and F Wilkinson, Labour Standards: Essential to Economic and Social Progress (London, Institute of Employment Rights, 1996).

${ }^{8}$ See further D Harvey, The Condition of Postmodernity: An Enquiry into the Origins of Cultural Change (Oxford, Blackwell, 1989).

${ }^{9}$ S Fredman, 'Precarious Norms for Precarious Workers' in J Fudge and R Owens (eds), Precarious Work, Women and the New Economy: The Challenge to Legal Norms (Oxford, Hart Publishing, 2006) 174, 184.

${ }^{10} \mathrm{See}$, eg, A Bogg and KD Ewing, 'The Continuing Evolution of European Labour Law and the Changing Context for Trade Union Organizing' (2017) 38 Comparative Labor Law \& Policy 211.

${ }^{11}$ Fudge and Owens, 'Precarious Work' (n 3 ) 14-15.

${ }^{12} \mathrm{~J}$ Fudge and B Cossman, 'Privatization, Law, and the Challenge to Feminism' in B Cossman and J Fudge (eds), Privatization, Law, and the Challenge to Feminism (Toronto, Toronto University Press, 2002) 3.

${ }^{13}$ S Fredman, 'Women at Work: The Broken Promise of Flexicurity' (2004) 33 Industrial Law Journal 299; S Fredman, 'The Ideology of New Labour Law' in C Barnard, S Deakin and GS Morris (eds), The Future of Labour Law: Liber Amicorum Bob Hepple QC (Oxford, Hart, 2004) 9.
} 
such as the decline in manufacturing and the rise of a new economy based on modern information-based systems, and technologies, have all contributed to a 'rapid disintegration of the old industrial model of employment' ${ }^{14}$ In legal terms, there has been a proliferation of nonstandard contractual arrangements which govern the work relationship, including: part-time work; fixed-term work; temporary agency work; dependent self-employment; and work on the basis of zero hour contracts. ${ }^{15}$ The level of protection afforded to such workers by law varies. Particular concerns arise, however, in relation to dependent self-employment ${ }^{16}$ and work on the basis of zero hours contracts ${ }^{17}$; both of which are growing phenomena in the UK, and are often associated with insecurity, precarity, and limited, if any, employment rights. In 2016, it was estimated that close to one million workers were working under a zero-hours contract, and that self-employment had grown to 4.6 million. ${ }^{18}$

In recent years, work in the so-called gig economy has also undergone exponential growth. ${ }^{19}$ The gig economy is generally understood to include two main forms of work: 'crowdwork' and 'work on-demand via app' ${ }^{20}$ The former refers to a work situation where a series of tasks are completed through online platforms. The online platforms establish contact between individuals and organisations (eg, Uber). The latter describes a form of work where the execution of traditional working activities such as transport, clerical work, or cleaning is channelled through apps that are managed by firms who require minimum quality standards of service, and intervene in the selection and management of the workforce. ${ }^{21}$ A thorough review of work practices in the gig economy is provided elsewhere, ${ }^{22}$ however, to summarise, work within the gig economy is enabled by IT, and the internet is used to match supply and demand. Workers are required to be extremely flexible (which is often cited as a positive aspect of the work, but which leads to increased competition between workers, often on a global scale; to

\footnotetext{
${ }^{14}$ Fudge and Owens, 'Precarious Work' (n 3 ) 3.

${ }^{15}$ These are not mutually exclusive categories and additional variations also exist.

${ }^{16}$ The rise in self-employment was the subject of a Government Review published in 2016. See J Deane, SelfEmployment Review: An Independent Report (February 2016) $<$ https://www.gov.uk/government/publications/self-employment-review> accessed 3 November 2018. For a discussion, see M Freedland, 'The Deane Review of Self-Employment' (The Institute of Employment Rights, 3 March 2016) <http://www.ier.org.uk/blog/deane-review-self-employment> accessed 3 November 2018.

${ }^{17}$ See further Z Adams and S Deakin, Re-Regulating Zero Hours Contracts (Liverpool, Institute of Employment Rights, 2014).

${ }^{18}$ In 2016, the UK government ordered a review (the 'Taylor Review') of such employment practices. For a discussion of the Review's findings, see E McGaughey, 'Uber, the Taylor Review, Mutuality and the Duty Not to Misrepresent Employment Status' (2018) Industrial Law Journal <doi:10.1093/indlaw/dwy014> accessed 3 November 2018.

${ }^{19}$ Accurate figures are hard to come by, but some data is provided by R Smith and S Leberstein, Rights on Demand: Ensuring Workplace Standards and Worker Security in the On-Demand Economy (National Employment Law Project, September 2015).

${ }^{20}$ This is explored in great detail by V de Stefano, 'The Rise of the "Just-in-Time Workforce": On-Demand Work, Crowdwork, and Labor Protection in the "Gig-Economy"' (2016) 37 Comparative Labor Law \& Policy Journal 471; see also, the references in fns 1-2 of de Stefano.

${ }^{21}$ See further V De Stefano, The Rise of the 'Just-in-Time Workforce': On-Demand Work, Crowdwork and Labour Protection in the 'Gig-Economy' (International Labour Office, Conditions of Work and Employment Series No 71, 2016).

${ }^{22}$ de Stefano, 'Rise of the Just-in-Time Workforce"' (n 20).
} 
very long hours worked; and extremely low earnings); are afforded few, if any, labour protections; and are only remunerated for actual time worked and work completed.

How then can one classify work in the gig economy? Is it really a new form of 'standard' or 'non-standard' work? Within the context of the gig economy, one rarely comes across the term 'work', 'worker', or 'labour', thereby suggesting that this form of work is a separate and 'new' form of engagement. In practice, many platforms or firms classify their 'workers' as independent contractors. However, in most cases, the evidence suggests that workers are rarely operating independently ${ }^{23}$ and that, for many workers, money earned in the gig economy is an essential source of income. ${ }^{24}$ Against this background, de Stefano and Berg present a convincing argument that suggests 'gig economy work is simply twenty-first century casual work rebranded'. ${ }^{25}$ Thus, contractual models such as zero-hours contracts, bogus selfemployment, or agency work can also occur within the gig economy. Worker profiles in the gig economy vary from highly skilled IT and creative professionals to unskilled workers. ${ }^{26}$ However, Cherry argues that in its extreme form, and particularly in the area of unskilled or low-skilled work, work in the gig economy-while not necessarily different from other nonstandard forms of work in terms of contractual arrangement - is a 'return to industrial (or even pre-industrial in terms of its pay by the piece and work at home) systems ... featur[ing] highly rigid control systems and deskilled work' ${ }^{27}$ Work in the gig economy must therefore be seen as a continuation of the rise in non-standard forms of work identified above, and will be considered under the broader umbrella of non-standard work for the remainder of this chapter. ${ }^{28}$

\section{Non-Standard Work, the Gig Economy, and Gender}

The language of atypical, precarious, crowdwork, work on demand, or non-standard work suggests that these 'new' forms of work differ from 'standard' work; ie, 'a full-time and yearround employment relationship for an indefinite duration with a single employer' ${ }^{29}$ However, this normative understanding of the standard employment relationship relied upon particular parameters - the growth of heavy manufacturing industries after World War II; and a clear

\footnotetext{
${ }^{23}$ This was confirmed by the employment tribunal in Aslam v Uber BV [2017] IRLR 4.

${ }^{24}$ De Stefano, Rise of the 'Just-in-Time Workforce' (n 21).

$25 \mathrm{~J}$ Berg and V De Stefano, 'It's Time to Regulate the Gig Economy' (Speri, 18 April 2017) $<$ http://speri.dept.shef.ac.uk/2017/04/18/its-time-to-regulate-the-gig-economy/> accessed 16 November 2018.

${ }^{26}$ See further G Valenduc and P Vendramin, 'Work in the Digital Economy: Sorting the Old from the New' (European Trade Union Institute, Working Paper 2016.03) $33<$ https://www.etui.org/Publications2/WorkingPapers/Work-in-the-digital-economy-sorting-the-old-from-the-new> accessed 16 November 2018.

${ }^{27}$ MA Cherry, 'Beyond Misclassification: The Digital Transformation of Work' (2016) 37 Comparative Labor Law \& Policy Journal 577, 601-2.

${ }^{28}$ There is an entire debate in the literature on whether there is a difference between this form of work and others. Space precludes discussion of the debate here. See further B Rogers, 'Employment Rights in the Platform Economy: Getting Back to Basics' (2016) 10 Harvard Law \& Policy Review 479; J Prassl, 'Reconsidering the Notion of "Employer" in the Era of the Fissured Workplace in the UK: Should Labour Law Responsibilities Exceed the Boundary of the Legal Entity?' (2017) 95 Bulletin of Comparative Labour Relations 81; the contributions in G Davidov and B Langille (eds), The Idea of Labour Law (Oxford, Oxford University Press, 2011).

${ }^{29}$ Fudge and Owens, 'Precarious Work' (n 3 ) 3.
} 
work-life arrangement whereby men were primary breadwinners, while women stayed at home and had primary care responsibilities. ${ }^{30}$ As Deakin points out, the standard employment relationship was based upon 'an anachronistic notion of the division of labour in the household' ${ }^{31}$ The increase in precarious or non-standard work undermines labour law, and labour institutions, which have been created around the concept of standard employment relationships. Yet the dichotomy in language ignores the nature of women's work-during this and earlier periods - which was often concentrated in precarious or 'non-standard' work (which, for them, was 'standard') that sought to supplement the declining male wage, but did not provide sufficient income for independence. ${ }^{32}$ As more men are working in precarious forms of work-previously identified with women-the language of the 'standard' employment relationship loses credibility, and we see a shift away from the male breadwinner model towards a 'feminisation of work'. 33

'Feminisation' in this case has a double meaning, referring both to 'the increased labour market participation of women and the proliferation of forms of employment historically associated with women, that is, jobs that are part time, temporary, poorly paid, and lacking benefits and collective forms of representation'. ${ }^{34}$ This is not to say that there has been complete convergence between men and women's work, as occupational gender segregation and equal pay differentials persist. ${ }^{35}$ The feminisation of work in this dual sense also permeates work in the gig economy. It is becoming increasingly widespread in sectors traditionally occupied by women, and female participation in the gig economy is also high. The idea that work can be done outside a 'standard' workplace, and fit around workers' other responsibilities (such as care responsibilities), harks back to an earlier time when women's work often took place in their own or someone else's home. ${ }^{36}$ The gender pay gap prevalent in other sectors of work also exists in the gig economy, where women experience discrimination at the hands of algorithms or ratings which are used to allocate work. ${ }^{37}$ In a recent survey completed in the US, a third of female gig workers adopted a gender neutral username in order to maintain

\footnotetext{
${ }^{30}$ See further J Conaghan, 'The Invisibility of Women in Labour Law: Gender-Neutrality in Model-Building' (1986) 14 International Journal of the Sociology of Law 377; Fredman, 'Labour Law in Flux' (n 6); L Dickens, 'Problems of Fit: Changing Employment and Labour Regulation' (2004) 42 British Journal of Industrial Relations 595.

${ }^{31}$ S Deakin, 'The Many Futures of the Contract of Employment' in J Conaghan, RM Fischl and K Klare (eds), Labour Law in an Era of Globalization: Transformative Practices and Possibilities (Oxford, Oxford University Press, 2004) 177.

${ }^{32}$ J Fudge and L Vosko 'Gender Paradoxes and the Rise of Contingent Work: Towards a Transformative Feminist Political Economy of the Labour Market' in W Clement and LF Vosko (eds), Changing Canada: Political Economy as Transformation (Montreal, McGill-Queen's University Press, 2003) 183; R Owens, 'Decent Work for the Contingent Workforce in the New Economy' (2002) 15 Australian Journal of Labour Law 209.

${ }^{33}$ Fudge and Owens, 'Precarious Work' (n 3).

${ }^{34}$ ibid, 12.

35 ibid.

${ }^{36}$ See N Schoenbaum, 'Gender and the Sharing Economy' (2016) 43 Fordham Urban Law Journal 1023; DE Roberts, 'Spiritual and Menial Housework' (1997) 9 Yale Journal of Law and Feminism 51.

${ }^{37}$ See M Kullmann, 'Platform Work, Algorithmic Decision-Making, and EU Gender Equality Law' (2018) 34 International Journal of Comparative Labour Law and Industrial Relations 1.
} 
anonymity. ${ }^{38}$ As Valenduc and Vendramin point out, the flexible nature of work in the gig economy entrenches gender segregation in the private sphere and reproduces gender power. ${ }^{39}$

\section{Challenges to Trade Unions}

The 'non-standard' worker is thus increasingly becoming the 'standard' worker. Yet, from an institutional perspective, there have been limited attempts at comprehensive reform of the 'classical' labour law model, which 'may be seen as a triangle whose three sides are companies, trade unions, and the state'. ${ }^{40}$ Trade unions, in particular, have struggled to move away from the basic post-war model of which they were an integral part, and upon which collective bargaining systems were premised. Although the growth in non-standard work has long been considered problematic - and has been the subject of much debate in the academic literature $^{41}$ - much of this debate takes as its point of departure the 'standard' (male) worker and considers the challenges posed by the recent growth in non-standard work. This is despite the fact that, since their inception, trade unions have been challenged by 'non-standard' work, which is described by the Webbs as work carried out by 'casual workers with no skills who are chiefly the daughters, wives and widows of these men who turn to labor of this kind'. ${ }^{4}$ According to the Webbs, it is

for ever hopeless to attempt, by Mutual Insurance or Collective Bargaining, to raise appreciably the wages of the common run of women workers. Where, as is usually the case, female labor is employed for practically unskilled work, needing only the briefest experience; or where the work, though skilled, is of a kind into which every woman is initiated as part of her general education, no combination will ever be able to enforce, by its own power, any Standard Rate, any Normal Day, or any definite conditions of Sanitation and Safety. ${ }^{43}$

If this is the premise, then it is perhaps not surprising that trade unions have historically been largely ineffective in organising women. Indeed, Secombe, writing in the 1970s, demonstrates how women, and housewives in particular, challenge the organised labour movement by remaining as a 'massive labouring population [...] completely outside the organizations and

38 C MacFarlane, 'The Future of Gig Work is Female' (Hyperwallet, 30 August 2017) < https://www.hyperwallet.com/resources/ecommerce-marketplaces/the-future-of-gig-work-is-female/> accessed 16 November 2018.

${ }^{39}$ Valenduc and Vendramin, 'Work in the Digital Economy' (n 26) 37.

${ }^{40}$ A Supiot, Beyond Employment: Changes in Work and the Future of Labour Law in Europe (Oxford, Oxford University Press, 2001).

${ }^{41}$ For an overview, see H Arthurs, 'Labour Law After Labour' in G Davidov and B Langille (eds), The Idea of Labour Law (Oxford, Oxford University Press, 2011) 13; R Gumbrell-McCormick and R Hyman, Trade Unions in Western Europe: Hard Times, Hard Choices (Oxford, Oxford University Press, 2013).

${ }^{42} \mathrm{~S}$ Webb and B Webb, Industrial Democracy (London, Longmans, Green \& Co, 1902) 757, quoting from C Booth (ed), Life and Labour of the People, vol 9 (London, Macmillan, 1897) 193.

43 ibid 757-58. 
struggles of the proletariat'. ${ }^{44}$ Rather than seeking to represent such 'workers', trade unions often played a significant part in maintaining women's disadvantage in the labour market. ${ }^{45}$

Between 1888 and 1918, overall trade union membership in the UK grew from 750,000 to six and a half million. The number of women members also increased during that period. However, by 1910, women made up almost one third of the workforce but only 10 per cent of members; over 90 per cent of women workers remained unorganised. Although women were incorporated in mixed unions, in sectors such as the cotton and textile industries where they often outnumbered male operatives (a high proportion of women were also members of teaching, clerical, and shop workers' unions), for the most part, women organised themselves. Trade union opposition to women workers-notably their concerns regarding equal pay and treatment - continued well into the twentieth century, even though female participation in the labour market, especially in traditionally male-dominated industries, increased during both world wars. ${ }^{46}$ Following the Second World War, in particular, women became a far more visible part of the paid work-force than in earlier periods. However, Fredman notes that 'the trade union movement was surprisingly slow to reflect the increased participation of women in the paid work-force' and it was not until the 1960s, with the growth of white collar trade unionism, that trade unions began to systematically recruit women workers. Today, also as a result of the decline in heavy industry, women trade union members outnumber men and the average British trade unionist is a young, degree-educated, white, professional woman (although it may be of little comfort to find that women's influence is expanding in a labour movement that is declining). Nonetheless, trade unions have often failed to adapt their structures to the changing make-up of the labour force and to changing employment relationships. As Cobble states, the feminisation of unions does not necessarily reflect a change in attitude to women workers by trade unions, but is 'a result of the decline of private sector unionism, which tends to be male-dominated, and the rise of public sector unionism, a sector in which large numbers of women work' ${ }^{47}$ In addition, a large proportion of women members are not always reflected in the demographics of branch officers, workplace representatives, and national officers. As a result, trade unions are struggling to shake off their image as the representatives of white, working-class, blue-collar men. ${ }^{48}$

The rise in the gig economy has added an extra layer of complexity to the challenges facing trade unions, as well as injecting a sense of urgency into the debate on how trade unions should respond to the rise in non-standard work. According to Huws, 'one way of looking at the recent exponential growth of online platforms in service delivery is to see it as a formalisation of the

\footnotetext{
${ }^{44}$ W Secombe, 'The Housewife and Her Labour under Capitalism' (1974) 83 New Left Review 3.

${ }^{45}$ Although there have been some exceptions. See further, the growing literature on trade unions and the feminisation of the labour market.

See, eg, Fredman, Women and the Law (n 2); L Briskin and P McDermott (eds), Women Challenging Unions: Feminism, Democracy, and Militancy (Toronto, University of Toronto Press, 1993); S Boston, Women Workers and the Trade Unions (London, Lawrence \& Wishart, 1987).

${ }^{46}$ See Fredman, Women and the Law (n 2).

${ }^{47}$ DS Cobble, Gender Equality and Labor Movements: Toward a Global Perspective (Solidarity Center, 2013) $12<\mathrm{http}$ //www.eldis.org/document/A101076> accessed 16 November 2018.

${ }^{48}$ This is due, in part, to the under-representation of women within trade unions; but even where this was not the case, women's domestic responsibilities made it difficult for them to participate actively in a trade union. See Fredman, Women and the Law (n 2) 137.
} 
informal economy, with the transparency of an open market replacing the old word-of-mouth methods of finding work' ${ }^{49}$ The lack of human contact and the wide dispersal of people across large geographical areas poses a particular challenge for trade unions; one that does not exist in the same way for other non-standard forms of work. This (again) raises the question of how to organise, represent, and regulate non-standard work at a time of union decline ${ }^{50}$ and limited legislative support. The move to individual rights, rather than a labour law system which includes collective bargaining (outlined above), underlines this dilemma for unions ${ }^{51}$ and 'weakens trade union capacity to regulate work and employment within the national boundaries in which they are embedded'. ${ }^{52}$ Moreover, 'changes in social values and expectations of workers towards unions, ${ }^{53}$ have forced unions to reassess their traditional role as worker associations.

In light of the nature of work in the gig economy - precarious and often low-skilled - it is therefore, perhaps, not surprising that we find certain parallels with women worker attempts at organising in the nineteenth century. In the gig economy, much of the organisation of workers has occurred outside established union structures, and there is limited evidence that traditional trade unions have been able to successfully organise non-standard workers. ${ }^{54}$ Most responses have focused on litigation. ${ }^{55}$ Thus, in the UK, there have been recent victories by unions over the taxi app, Uber; the food delivery empire, Deliveroo; and the delivery firm, CitySprint ${ }^{56} \mathrm{At}$ the EU level, in FNV Kunsten Informatie en Media v Netherlands, ${ }^{57}$ the European Court of Justice (ECJ) ruled that competition law does not apply to collective agreements amongst freelance substitute orchestra musicians, which aim to improve their working conditions, if they can be classed as 'workers' (to be determined by national law) rather than 'undertakings'. In light of recent decisions in the UK, which have held that non-standard workers are to be classified as 'workers' even if their contract says otherwise, the ECJ's ruling opens the door for trade unions to include 'false self-employed' non-standard workers, who have a position that to all intents and purposes is similar to that of a standard worker in collective agreements.

The fact that trade unions are focusing strongly on litigation as a response to the rise of the gig economy is indicative of the way in which trade union strategies have changed over the

49 U Huws, 'Logged In' Jacobin (6 January 2016) <https://www.jacobinmag.com/2016/01/huws-sharingeconomy-crowdsource-precarity-uber-workers/> accessed 16 November 2018.

${ }^{50}$ See further, Special Issue: Union Decline: Causes, Consequences and Cures (2011) 17(2) European Journal of Industrial Relations 95-203.

${ }^{51}$ Equally, much of the literature that has considered alternative conceptions of 'worker' - in order to encompass workers in the gig economy - does not seem to move away from the individualised approach.

52 Gumbrell-McCormick and Hyman, Trade Unions in Western Europe (n 41) 29.

${ }^{53}$ B Ebbinghaus and J Visser, 'When Institutions Matter: Union Growth and Decline in Western Europe, 19501995’ (1999) 15 European Sociological Review 135, 143.

${ }^{54}$ For an overview of recent campaigns in the UK, see Trade Union Congress, Written Evidence (WOW0062) to Business, Energy and Industrial Strategy Committee, The Future World of Work and Rights of Workers Inquiry,

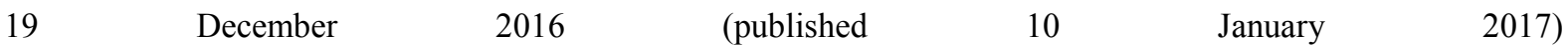

$<$ http://data.parliament.uk/writtenevidence/committeeevidence.svc/evidencedocument/business-energy-andindustrial-strategy-committee/future-world-of-work/written/44647.html> accessed 17 November 2018.

${ }^{55}$ See further, Cherry, 'Beyond Misclassification' (n 27), for litigation that has taken place in the UK.

${ }^{56}$ Not all of these cases involved 'traditional' trade unions. The Uber case involved the GMB, whilst the Deliveroo and CitySprint cases were supported by the Independent Workers' Union of Great Britain.

57 [2015] 4 CMLR 1 (ECJ, First Chamber). 
years. The same observation can be made in relation to calls for legislative action by trade unions which have become widespread. ${ }^{58}$ As Bogg and Ewing point out, using litigation as a political strategy, or calling for greater government involvement, highlights

the extent to which British trade unions have reconceived their methods of engagement. Historically, of course, it was one of the defining features of collective laissez-faire that British trade unions operated on the basis of a distrust of courts. As the political and constitutional landscape has shifted, the forms of trade union action have undergone a transformation as well. ${ }^{59}$

In light of falling trade union membership, a decline in trade union density, and limited legislative support for trade unions, Wedderburn suggested in 2007 that the 'union movement could no longer sustain the weight of a "collective laissez faire" model'. ${ }^{6}$

Looking at trade union responses to workers in the gig economy seems to confirm Wedderburn's scepticism. Despite some success in the courts for 'traditional' trade unions, much of the litigation has been taken by the Independent Workers Union of Great Britain (IWGB). The IWGB was founded in 2012 and is a small, independent trade union-not affiliated with the TUC - whose members are predominantly low paid migrant workers in London. In its work, the IWGB focuses on high-profile campaigns and member representation, and also provides very limited services (mainly English language classes). It does not seek regulation of the labour market more generally. Thus far, it has acted as a dynamic and cooperative model with very limited or no hierarchies (in contrast to the democratic centralism which characterises 'traditional' trade unions ${ }^{61}$ ), and with noticeable success in organising and campaigning within specific sectors dominated by non-standard (male and female) workers, including for couriers working in the gig economy.

The success of the IWGB in organising non-standard workers raises the question as to whether 'traditional' trade unions are able to effectively respond to the rise of non-standard forms of work, and to the gig economy, in particular. It is suggested that part of the difficulty for these trade unions lies in the way in which they prioritise the functions adopted by them within the labour market and the labour law system; functions which are based on a gendered understanding of 'norms of employment, assumptions about who workers are and what they need, and ideas about how regulation works ${ }^{62}$ which, in turn, hamper trade union efforts to

\footnotetext{
${ }^{58}$ See, for example, the statements made by Hannah Reed (Senior Employment Rights Officer, TUC) to the House of Commons' Business, Energy and Industrial Strategy Committee's Inquiry into the Future World of Work: Hannah Reed, Trade Union Congress, Oral Evidence (HC 929) to Business, Energy and Industrial Strategy Committee, The Future World of Work and Rights of Workers Inquiry, 7 March 2017 $<$ http://data.parliament.uk/writtenevidence/committeeevidence.svc/evidencedocument/business-energy-andindustrial-strategy-committee/future-world-of-work/oral/48743.html> accessed 17 November 2018.

${ }^{59}$ Bogg and Ewing, 'Continuing Evolution of European Labour Law' (n 10) 226. Bogg and Ewing are referring here to the Unison litigation over the introduction of tribunal fees; however, similar lessons can be drawn from the litigation surrounding the gig economy cases. On collective laissez faire, see AD Flanders, 'The Tradition of Voluntarism' (1974) 12 British Journal of Industrial Relations 352.

${ }^{60}$ Wedderburn, 'Labour Law 2008' (n 6) 405.

${ }^{61}$ See U Mückenberger, E Schmidt and R Zoll (eds), Die Modernisierung der Gewerkschaften in Europa (Westfälisches Dampfboot, 1996) 12.

${ }^{62}$ Fudge and Owens, 'Precarious Work' (n 3 ) 3.
} 
reach out to a feminised - in both senses of the word - labour force. The next section therefore considers the extent to which the functions adopted by trade unions in the UK display gendered understandings of the labour market and the labour law system.

\section{Trade Union Functions}

Keith Ewing identifies five principal functions of unions: a service function; a representation function; a regulatory function; a government function; and a public administration function. ${ }^{63}$ The different functions sit along a scale, with the service function at one end as the 'activity of a fledgling and immature organisation', and the public administration function at the other representing 'the apotheosis of trade union ambition in a social democratic society'. ${ }^{64}$ The ambit of each function is largely self-evident. According to Ewing, 'a service function means a function which involves the provision of services and benefits to members'. ${ }^{65}$ The meaning of the representation function is, again, obvious. All trade unions represent the interests of the worker at their place of work. This occurs through individual representation-ie, an extension of the union's service function - or collective representation, where overlaps occur with the regulatory function. Rule-making through collective bargaining, which is limited to individual members of the trade union, will thus fall under the umbrella of the representation function whereas the regulatory function 'acknowledges that trade unions are involved in a process of rule-making that extends beyond their members or the immediate colleagues of their members' ${ }^{66}$ Finally, the governmental and public administration functions of trade unions have two dimensions: first, trade unions represent 'the organised political representation of working people, both as a means of restraining the power of the State and a means of harnessing the power of the State'; ${ }^{67}$ secondly, trade unions engage 'in the process of government in the sense of being involved in the development, implementation and delivery of government policy'. ${ }^{68}$ Ewing's analysis of trade union functions took place against the background of New Labour's 'Third Way', where trade unions were encouraged to provide both a universal service function to all and any workers wishing to become members, and to 'cooperate' with employers in representing members. ${ }^{69}$ Trade unions thus expanded their service function in relation to work (by providing inter alia legal representation), but also outside of work (by offering commercial or social services) ${ }^{70}$ and changed their way of working to support 'partnership industrial relations'. ${ }^{71}$ The latter policy was most visible in relation to industries that required a 'flexible, skilled and motivated workforce', ${ }^{72}$ and where trade unions are established.

\footnotetext{
${ }^{63}$ KD Ewing, 'The Function of Trade Unions' (2005) 34 Industrial Law Journal 1.

${ }^{64}$ ibid 3.

65 ibid.

66 ibid 4.

67 ibid 5.

68 ibid 5.

69 ibid, section 3 .

70 ibid 7.

${ }^{71}$ On partnership and unions, see T Novitz, 'A Revised Role for Trade Unions as Designed by New Labour: The Representation Pyramid and "Partnership"” (2002) 29 Journal of Law and Society 487.

72 Department of Trade and Industry, Fairness at Work (Cm 3968, 1998) para 4.7.
} 
However, the policy has had limited impact on women workers: trade unions still lack a presence in sectors dominated by non-standard work, where 'flexibility' usually equates to numerical (which results in precarity) rather than functional flexibility. ${ }^{73}$

At the same time, the regulatory role of collective bargaining receded due to lack of public policy support and the abolition of an appropriate legal structure to accommodate, and support, such a function. Regulation of work has become a State rather than a trade union responsibility ${ }^{74}$ with unions' 'regulatory ambitions to be secured by political campaigning and by legislation rather than by collective bargaining'. ${ }^{75}$ While New Labour sought to encourage more women to participate fully in the labour market through the introduction of familyfriendly norms (in contrast to earlier State preferences) ${ }^{76}$, gender inequalities were not directly addressed; and although women and non-standard workers were beneficiaries of many of New Labour's initiatives, the primary drive behind many of the labour law measures was efficiency rather than fairness considerations. This has only increased in recent years. ${ }^{77}$ As a result, there has been a dilution of norms which seek to benefit non-standard workers but which, because of their underlying policy rationale, are not as effective as they could be. The recommendations which have been made as a result of the current Government's review into 'modern working practices' are a case in point. ${ }^{78}$ It is therefore not surprising that the working patterns of women - predominantly in low-paid, precarious work - have not changed substantially.

Ewing's analysis of trade union functions is based on his observations of organisations that are characterised by democratic centralism and a hierarchical power structure. ${ }^{79}$ Their functions reflect their historical legacy as well as their members' priorities. These unions have long struggled to reach out to workers who do not fit within the mould of the 'standard' worker. During the nineteenth and the first half of the twentieth century, there was no desire or perceived need to engage with non-standard or women workers. Although trade union attitudes to women workers have since fundamentally changed, where they have been successful in organising women, this has largely been restricted to white collar professionals who slot more easily into the 'standard' worker paradigm. However, unions continue to struggle to respond effectively to the majority of women workers who are employed in non-standard work. By extension, it is not surprising that they are also challenged by the rise in non-standard work amongst male workers and the growth of the gig economy.

\footnotetext{
${ }^{73}$ On the distinction between the two, see J Atkinson, Flexibility, Uncertainty and Manpower Management (The Institute for Employment Studies, Report 89, 1985) <https://www.employment-studies.co.uk/resource/flexibilityuncertainty-and-manpower-management> accessed 17 November 2018.

${ }^{74}$ See P Davies and M Freedland, Labour Legislation and Public Policy: A Contemporary History (Oxford, Clarendon Press, 1993) ch 1.

${ }^{75}$ Ewing, 'Function of Trade Unions' (n 63) 15.

${ }^{76}$ See Fredman, 'Precarious Norms' (n 9).

${ }^{77}$ Examples of this are evident in the recent welfare reforms, as well as any attempts to regulate non-standard work, including the recommendations of the Taylor Review.

${ }^{78}$ See IER (The Institute of Employment Rights) summaries of the different recommendations: 'The IER Guide to the Taylor Review' (The Institute of Employment Rights, 13 July 2017) < http://www.ier.org.uk/news/ier-guidetaylor-review> accessed 17 November 2018.

${ }^{79}$ Crain convincingly argues that power structures, which reflect patriarchal visions of power, sacrifice the solidarity that once served as the source of workers' empowerment. See M Crain, 'Feminism, Labor, and Power' (1992) 65 Southern California Law Review 1819.
} 


\section{Rethinking of Priorities?}

In order to effectively respond to non-standard workers, including workers in the gig economy, this chapter concludes by calling for a new research agenda which requires trade unions to confront problems that women workers have struggled with for decades, and develop innovative strategies which take account of women's work and women's experience; insights from the gender domain could facilitate an effective response to the rise in non-standard work. ${ }^{80}$ A successful reaching out to non-standard workers will also enhance the effectiveness of industrial relations law, and practice, by broadening unions' representational base and strengthening their claims to act as worker representatives and work regulators. Since nonstandard work is fast becoming the norm, and shows no signs of abating, unions have to shift their focus to a new 'standard' worker - one long neglected by unions. It is argued that this shift in focus must begin with a shift in priorities relating to different functions, and to issues within those functions.

Ewing singles out the regulatory function as 'the most important function of trade unions, this being the most visible manifestation of the trade union role in promoting fairness and social justice not only at work but within the economy as a whole'. ${ }^{81}$ The service function, on the other hand, can be found at the bottom end of the scale as 'the activity of a fledgling and immature organisation'. ${ }^{82}$ The focus on regulation as the ultimate goal of trade union action persists, even though the most successful trade union responses to non-standard workers to date-particularly workers in the gig economy-have centred on the service function (the successful actions of the IWGB are a case in point). The devaluation of the service function hinders trade unions in terms of identifying and placing matters of concern to these workers centre-stage. This is not to say that trade unions should abandon their goal of seeking to regulate work through collective bargaining. There are examples of trade unions in other countries that manage to successfully bargain on behalf of non-standard workers. ${ }^{83}$ However, collective bargaining, as traditionally conceived, proceeds on the presumption that trade unions represent a majority of workers in individual work-sites and negotiate collective agreements for individual groups of workers (or sectors); neither of these presumptions hold for non-standard workers. In addition, bargaining and work regulation in this regard often concerns industrial or economic matters, which are of secondary concern to workers who have limited or no job security, or access to employment rights. Issues of relevance to non-standard workers such as job segregation, (numerical) worker flexibility, and a systematic undervaluing of their work

\footnotetext{
${ }^{80}$ ibid; A Forrest, 'A View from Outside the Whale: The Treatment of Women and Unions in Industrial Relations' in L Briskin and P McDermott (eds), Women Challenging Unions: Feminism, Democracy, and Militancy (Toronto, University of Toronto Press, 1993) 325. Fudge therefore calls for 'the development of new forms of broader-based bargaining and inclusive unionism which do not replicate and reinforce the deeply fragmented, gendered, and hierarchical labour market which currently exists': J Fudge, 'The Gendered Dimension of Labour Law: Why Women Need Inclusive Unionism and Broader-Based Bargaining' in L Briskin and P McDermott (eds), Women Challenging Unions: Feminism, Democracy, and Militancy (Toronto, University of Toronto Press, 1993) 231, 244.

${ }^{81}$ Ewing, 'Function of Trade Unions' (n 63) 13.

82 ibid 3 .

${ }^{83}$ See Cobble, Gender Equality and Labor Movements (n 47).
} 
are considered social or equality issues. ${ }^{84}$ Those examples where trade unions have been successful at organising, and bargaining, on behalf of non-standard workers have occurred where unions have broadened their bargaining agenda to prioritise, for example, equal pay, the elimination of discrimination, the provision of childcare at work, and the opening up of employment and training opportunities to non-standard (women) workers. ${ }^{85}$

The service function as traditionally conceived by trade unions-legal advice at work, discounts for insurance or holidays, and so on-fails to take into account the precarious and flexible nature of non-standard work. Such services will be of little appeal to workers who, for example, struggle to combine childcare and work, or who do not know how many hours they will work in any given week. Instead, trade unions need to think much more deeply about the types of services that could empower non-standard workers to better represent themselves, visà-vis a range of different actors such as employers, government officials, or consumers. In rethinking the service function, they could, for example, act as a form of employee mutual. Cautious parallels can be drawn with the labour market of the nineteenth century, where it was often not possible for trade unions to bargain with employers concerning regulation of the employment relationship; both because of the craft nature of many jobs (which entailed unilateral regulation), and because of the extreme precariousness and instability of many employment relationships, such as the casual (female) labourers identified by the Webbs above, and where the weakness of public social protections required the direct assumption of solidaristic tasks by trade unions. ${ }^{86}$ British trade unions therefore controlled the labour supply, and supplied - and (where possible) bargained for- 'friendly benefits' and allowances for workers. As Cella highlights, this was the typical action of trade union representation before the spread of the 'new unionism'; ${ }^{87}$ namely, to bargain minimum standards with employers and provide fairness criteria around which to organise unilateral regulation. The distribution of benefits (in case of accident, illness, or unemployment) served the same purpose: to ensure that a temporary or permanent decline in the market power of individuals did not prompt breach of the wage levels, and employment conditions, established by custom or tradition. ${ }^{8}$ In the labour market of the twenty-first century, many of these benefits are provided by the State. However, due to the nature of the work relationship, non-standard workers often either do not qualify for such benefits, or they are so meagre that they do not prevent workers from taking on jobs that undermine established wage levels or employment conditions-thereby leading to a dehumanisation of the workers, and increasing precarity across the labour market.

It must, of course, be borne in mind that these nineteenth century trade union policies are associated with 'craft unions', where workers organised along the lines of a particular craft,

\footnotetext{
${ }^{84}$ See A Blackett and C Sheppard, 'Collective Bargaining and Equality: Making Connections' (2003) 142 International Labour Review 419, 432.

${ }^{85}$ For examples, see Cobble, Gender Equality and Labor Movements (n 47).

${ }^{86}$ The parallels between the end of the nineteenth and twentieth centuries was also remarked upon by Dahrendorf: R Dahrendorf, Economic Opportunity, Civil Society and Political Liberty (Geneva, United Nations Research Institute for Social Development, 1995).

${ }^{87}$ See further EJ Hobsbawm, Worlds of Labour: Further Studies in the History of Labour (London, Weidenfeld \& Nicholson, 1984) ch 9.

${ }^{88}$ See HA Clegg, A Fox and AF Thompson, A History of British Trade Unions since 1889, vol 1 (Oxford, Clarendon Press, 1964) 6-7.
} 
occupation, or trade within local and controllable labour markets (thereby discriminating against 'outsiders' to the craft); and that, of course, women were often excluded from craft unions. However, research in recent decades, especially in North America, has shown that elements of these policies can be used in today's context with regard to unskilled jobs in services, and to the high-tech jobs of semi-self-employment in the gig economy. ${ }^{89}$ In this context, it must be questioned whether it is possible to change trade union behaviour, or whether non-standard workers would be better served by the establishment of new trade unions. This chapter does not seek to advocate in favour of one or the other, but suggests that if 'traditional' trade unions are to respond to the rise in non-standard work, then they must reconsider how they prioritise and think about their functions in the contemporary labour market. Although newer trade unions have led the way in responding to non-standard workers, 'traditional' trade unions benefit from an institutional memory, credibility, and organisational structures which are invaluable. If they were to take on solidaristic tasks, which involve a financial commitment such as acting as an employee mutual, then 'traditional' trade unions tend to have greater financial means than newer trade unions. This is particularly the case amongst general unions that cover a number of different sectors where risks and financial burdens could be shared. Finally, 'traditional' trade unions often have links with established political parties which may give them greater political influence. Changing trade union behaviour is undeniably difficult. It involves thinking about the language used in recruiting non-standard (women) workers, encouraging the visibility of non-standard (women) workers as branch officers, workplace representatives, and national officers, and involving them in policy development. Recent campaigns launched by the TUC to recruit young workers suggest that there is a willingness to change. ${ }^{90}$ This chapter takes a first tentative step in that regard by calling for a new research agenda which places the challenges for trade unions surrounding non-standard work, and work in the gig economy, within the context of the feminisation of work. Against this background, future work should test this hypothesis by considering, in more detail, the gendered nature of trade union responses to non-standard work and comparing their responses with non-traditional trade unions, and other grass-roots organisations, to consider lessons that could be learnt in this regard.

\footnotetext{
89 See further GP Cella, 'The Representation of Non-Standard Workers: Theory and Culture of Collective Bargaining' (2012) 18 Transfer 171, 176.

90 See the TUC's WorkSmart model aimed at young workers: 'A Career Coach that Works for Everyone' (WorkSmart) <https://www.getworksmart.co.uk/> accessed 17 November 2018.
} 